\title{
PENGEVALUASIAN PROSES KEPERAWATAN YANG TELAH DILAKSANAKAN KEPADA PASIEN DIABETES MELLITUS
}

\author{
SRI HARVITA SARI MARPAUNG / 181101125
}

Sriharvitaaasm11@gmail.com

\begin{abstract}
ABSTRAK
Latar belakang : Pengevaluasian proses keperawatan merupakan proses lanjutan yang diberikan kepada pasien. Pengevaluasian akan memuat hasil dari awal pengkajian hingga penatalaksanaan, dalam proses ini akan diperoleh respon dari pasien apakah pasien dapat mencapai tujuan, sedang mencapai tujuan atau belum mampu mencapai tujuan dalam pemenuhan kebutuhan pasien.

Tujuan : mengetahui proses pengevaluasian proses keperawatan yang telah diberikan kepada pasien yang menderita diabetes melltitus. Metode : menggunakan literature riview berdasarkan teks book, jurnal, e-book (10 tahun terakhir) dengan cara menganalisis, eksplorasi sumber dan kajian bebas. Hasil : memberikan informasi pengevaluasian mengenai hasil yang didapatkan dari asuhan keperawatan kepada pasien yang menderita diabetes mellitus. Pembahasan : pengertian evaluasi keperawatan, tujuan evaluasi keperawatan bagi pasien DM, tahapan evaluasi keperawatan pada pasien DM. Kesimpulan : Pengevaluasian proses keperawatan pada pasien yang menderita penyakit DM bertujuan untuk mengetahui kemajuan dari kesehatan pasien apakah pasien telah mencapai tujuan, sedang dalam proses mencapai tujuan atau tidak bisa mencapai tujuan yang telah ditentukan. Dengan demikian dari hasil pengevaluasian proses keperawatan, perawat mampu mengambil keputusan yang tepat untuk masa perawatan yang akan diberikan pada pasien DM sehingga kebutuhan pasien terpenuhi dan kesehatan pasien dapat mengalami kemajuan.
\end{abstract}

Kata kunci : Asuhan Keperawatan, Pengevaluasian Keperawatan, Tujuan evaluasi Keperawatan, Tahapan Evaluasi Keperawatan.

\section{LATAR BELAKANG}

Diabetes melitus (DM) merupakan suatu penyakit dimana terjadi gangguan metabolisme karbohidrat, protein dan lemak. Hal ini diakibatkan oleh kurangnya sensitivitas otot ataupun jaringan terhadap insulin, yang disebut dengan resistensi insulin ataupun oleh kurangnya hormon insulin atau disebut dengan defisiensi insulin (Guyton \& Hall, 2007). Diabetes mellitus adalah suatu kumpulan gejala yang timbul pada seseorang disebabkan oleh adanya peningkatan kadar gula glukosa darah akibat kekurangan insulin baik absolut maupun relatif (Syahbudin, 2009). Bahaya diabetes sangat besar dan dapat memungkinkan penderita menjadi lemah ginjal, buta, menderita penyakit bagian kaki dan banyak komplikasi serius dan menyebabkan tingkat kematian yang tinggi. Penderita DM menghadapi bahaya setiap harinya 
karena kadar gula darah yang tidak terkontrol. Glukosa darah mengandung kadar yang berubah-ubah sepanjang hari terutama pada saat makan, dan beraktifitas (Pangestu, 2007).

Pengevaluasian proses keperawatan merupakan proses lanjutan dari pengkajian, diagnosa, perencanaan dan penatalaksanaan keperawatan yang diberikan kepada pasien. Pengevaluasian akan memuat hasil dari awal pengkajian hingga penatalaksanaan, dalam proses ini akan diperoleh respon/hasil yang akan diperoleh dari pasien apakah pasien dapat mencapai tujuan, sedang mencapai tujuan atau belum mampu mencapai tujuan dalam pemenuhan kebutuhan pasien.

\section{TUJUAN}

Tujuan dari penulisan kajian ini adalah untuk mengetahui proses pengevaluasian proses keperawatan yang telah diberikan kepada pasien yang menderita diabetes melltitus.

\section{METODE}

Metode yang digunakan dalam penulisan ini menggunakan literature riview berdasarkan teks book, jurnal, ebook (10 tahun terakhir) dengan cara menganalisis, eksplorasi sumber dan kajian bebas.

\section{HASIL}

Hasil yang diharapkan dari penulisan kajian ini adalah untuk memberikan informasi pengevaluasian mengenai hasil yang didapatkan dari pemberian asuhan keperawatan kepada pasien yang menderita diabetes mellitus.

\section{PEMBAHASAN}

Evaluasi keperawatan merupakan tindakan intelektual yang bertujuan untuk melengkapi proses keperawatan yang menandakan seberapa jauh diagnosa keperawatan, rencana tindakan keperawatan, dan pelaksanaannya sudah berhasil dicapai. Perawat dapat memonitor apa saja yang terjadi selama tahap pengkajian, diagnosa, perencanaan, dan pelaksanaan keperawatan yang telah dilakukan terhadap pasien yang ditangani.

Tujuan dari pengevaluasian keperawatan adalah untuk :

1. Melihat kemampuan pasien/klien dalam mencapai tujuan

2. Mengetahui respon pasien/klien terhadap tindakan keperawatan 


$$
\begin{aligned}
& \text { yang telah diberikan sehingga } \\
& \text { perawata dapat mengambil } \\
& \text { keputusan, seperti : } \\
& \text { - Mengakhiri rencana } \\
& \text { tindakan bila pasien telah } \\
& \text { mencapai tujuan yang } \\
& \text { telah ditetapkan di awal. }
\end{aligned}
$$

Proses dari pengevaluasian keperawatan yang telah dilakukan terdiri dari 2 tahap yaitu :

\section{Tahap mengukur pencapaian tujuan klien}

Tahap dalam mengukur pencapaian tujuan klien dapat dilihat dari 4 aspek berikut yaitu :

a. Kognitif (pengetahuan)

- Mengidentifikasi pengetahuan yang spesifik yang diperlukan setelah pasien diajarkan tentang teknik tertentu.

- Lingkup evaluasi : pengetahuan terhadap penyakit DM, mengontrol gejala gejala yang ditimbulkan oleh DM, pengobatan, diet, dan aktivitas fisik yang akan dilakukan.

- Evaluasi kognitif dapat diperoleh dari interview atau test tertulis.

b. Afektif (status emosional)

- Cenderung penilaian yang dilakukan subjektif dan sulit untuk dievaluasi.

- Hasil penilaian emosi ditulis dalam bentuk perilaku, seperti pasien dapat mengurangi rasa cemas terhadap gejala gejala yang ditimbulkan oleh penyakit DM.

- Didapatkan dari observasi langsung.

c. Psikomotor

- Penilaian dilakukan dengan observasi langsung pada perilaku 
sesuai dengan tujuan/kriteria hasil.

d. Perubahan fungsi tubuh dan gejala

- Evaluasi mencakup observasi langsung terhadap aspek status kesehatan pasien.

- Evaluasi dapat dilakukan dengan observasi secara langsung, interview dan pemeriksaan fisik.

\section{Penentuan keputusan}

Penentuan keputusan pada tahap evaluasi didasarkan pada 3 kemungkinan yaitu :

I. Pasien telah mencapai hasil yang ditentukan pada kriteria hasil/tujuan. Dalam hal ini perawat akan mengkaji masalah pasien lebih lanjut atau mengevaluasi outcomes yang lain.

II. Pasien masih dalam proses mencapai hasil yang ditentukan, dalam hal ini pasien masih memerlukan waktu tambahan, resource, dan tujuan intervensi yang mungkin diperlukan sebelum tujuan tercapai.
III. Pasien tidak dapat mencapai hasil yang telah ditentukan, dalam hal ini perawat harus mampu mengidentifikasi masalah yang menghambat pasien mencapai tujuan.

Pengevaluasian keperawatan pada pasien yang menderita diabetes mellitus disesuaikan dengan hasil yang telah diperoleh pada awal pengkajian, diagnosa, perencanaan dan penatalaksanaan asuhan keperawatan.

\section{KESIMPULAN}

Dalam memberikan asuhan keperawatan perawat perlu mengetahui hasil akhir yang diperoleh dari pemberian asuhan keperawatan tersebut. Pengevaluasian proses keperawatan pada pasien yang menderita penyakit diabetes mellitus bertujuan untuk mengetahui kemajuan dari kesehatan pasien apakah pasien telah mencapai tujuan, sedang dalam proses mencapai tujuan atau tidak bisa mencapai tujuan yang telah ditentukan. Dengan demikian dari hasil pengevaluasian prose keperawatan, perawat mampu mengambil keputusan yang tepat untuk masa perawatan yang akan diberikan pada pasien DM sehingga kebutuhan 
pasien terpenuhi dan kesehatan pasien dapat mengalami kemajuan.

\section{REFERENSI}

Almatsier, S. (2004). Penuntun Diet

Edisi Baru. Jakarta : PT Gramedia

Pustaka Utama.

Arjatmo. (2002). Penatalaksanaan

Diabetes Mellitus Terpadu Cetakan 2. Jakarta : Balai Penerbit FKUI.

Hutagalung H. (2004). Karbohidrat.

Bagian Ilmu Gizi Fakultas Kedokteran Universitas Sumatra Utara : USU digital library. Hal : 1-13.

Hincliff. (1999). Kamus Keperawatan. Jakarta : EGC.

Jauhar, M. (2013). Asuhan Keperawatan. Jakarta : Prestasi Pustaka Maulana, M. (2008). Mengenal Diabetes Melitus. Jogjakarta : Perpustakaan Nasional KDT.

Mubarak, W. I., Indrawati, L., Susanto, J. (2015). Buku Ajar Ilmu Keperawatan Dasar. Jakarta : Salemba Medika.

Nurarif, A. H. (2015). Aplikasi Asuhan Keperawatan Berdasarkan Diagnosa Medis dan NANDA NIC - NOC. Yogyakarta : Media Action.
Perkeni. (2006). Konsensus Pengelolaan dan Pencegahan Diabetes Melitus Tipe 2 di Indonesia. Jakarta : EGC.

Potter \& Perry. (2010). Fundamental of Nursing (fundamental Keperawatan). Buku 1. Edisi 7. Indonesia : Salemba Medika.

Potter \& Perry. (2010). Fundamental of Nursing (fundamental Keperawatan). Buku 3. Edisi 7. Indonesia : Salemba Medika.

Soegondo, S. Dkk. (2007).

Penatalaksanaan Diabetes Mellitus

Terpadu Cetakan 6. Jakarta : Balai Penerbit FKUI.

Supariasa,dkk. (2002). Penilaian Status Gizi. Jakarta : EGC. 